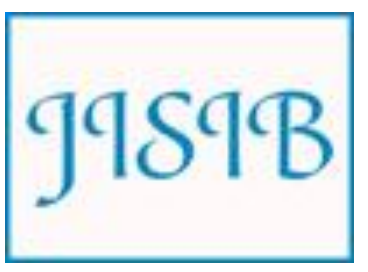

Available for free online at https://ojs.hh.se/

Journal of Intelligence Studies in Business 2 (2012) 59-67

\title{
Standards, Evaluation, Certification and implications for the study of Competitive Intelligence
}

\author{
Christian Bourret * \\ * University of Paris-East Marne-la-Vallée, France. \\ bourret@univ-mlv.fr
}

Received 10 December 2010; received in revised form 19 February 2011; accepted 27 April 2012

\begin{abstract}
The rise of standards, evaluations and certifications are expressions of what may be called the cult of performance and efficiency. Standards and assessment are frequently presented as inevitably, improving quality through a project approach. As such they reflect a strong focus on efficiency in a world dominated by the quantitative approach. These standards and evaluations may hinder Competitive Intelligence goals. Building on the interdisciplinarity of Information and Communication Sciences (ICS), we propose another qualitative approach to standards and assessment. Finally, we considers the challenges represented by standards in the context of globalization of the economy and of trade.
\end{abstract}

Keywords: Standards, evaluation, certification, competitive intelligence

\section{Introduction}

Standards have become increasingly important in our society. In 1997, the French sociologist L. Thévenot had already spoken of "government by the standards." Since then the phenomenon has been largely amplified, with a close link between standards, outsourcing and its control, and evaluation. Standards have also become a main issue in the process of globalization. Standards are considered as part of modern management, for private companies and for public institutions alike. Standards are also as a main issue in globalization, with the role of ISO and of the "society of risk" (U. Beck) and a key point in Risk Management. Standards also have strong interconnections with Competitive Intelligence stakes as the analyst sets out to predict future scenarios.

This article begins by demonstrating how the rise of standards, evaluation (assessment) and certification are a part of what we shall call the cult of performance and efficiency. Then we proceed by proving how standards and evaluation are important to improve service quality through a project approach. Standards can lead to an obsession with 
efficiency in a too exclusively quantitative approach. This ambivalence of standards and evaluation processes can involve contradictions with Competitive Intelligence goals and methods. Based on the interdisciplinary of Information and Communication Sciences (ICS), this article proposes another qualitative approach to standards and assessment. The perspective of this article is finally broadened by considering the challenges due to standards in the larger context of globalization.

\subsection{Standards, Assessment, Certification or the rise of the cult of Performance and Efficiency}

The concept of standards is ancient. In France, this term has a Latin origin (norme) and dates back to the year 1160. In the craft sector, guilds imposed a strict respect of the manufacturing processes. The French Revolution swept corporations away as vestiges of the "Old Regime", with the revolutionaries willing to change both the things that were made and the people. The revolution imposed new standards such as the metric system, a new calendar ("revolutionary"), and a new division of national territory (the departments replacing the provinces). Even in metrology aspect (weights and measures), standards have deep social influences. Other standards (calendar, administrative districts) constitute the basic framework of daily life in a developed society. Today standards frame information exchanges (Pdf, Excel and so on). All the classifications are not neutral and they imply debatable statistical classifications (for example of social categories ${ }^{1}$ ). Classifications condition people's representation and the vision of the future. As such it also affects the study of CI, as it decides how we look and try to analyze future events.

The Industrial Revolution relied on the standardization of production, particularly from the early twentieth century with the scientific organization of work advocated by F. Taylor. The accounting techniques, which appeared in Venice (Italy) in 1494, are also based on standards, to assess the revenue and expenditure of companies, to assess profit (development of Capitalism). According to Colbert's view in France in the seventeenth century (development of the administrative or absolute monarchy), the State point of view of standards are for tax purposes: French Accounting Plans of 1947 and 1982 met these two different goals.

Standards and assessment (evaluation) are thus an integral part of the Management that has

\footnotetext{
1 Classifications are never neutral: documentation and statistical bodies (INSEE in France) are linked to social categorizations and used to support any form of government, as with Apartheid in South Africa.
}

gradually emerged, following the pioneering works of the French engineer $H$. Fayol in the early twentieth century. This was also part of the main characteristic of the United States (departments of Management for example at Harvard University).

According to Le Moënne (2004), the big managerial disruption in the late eighties, corresponding to the spatial and temporal dislocation of companies, is probably the largest movement of managerial standards, most systematic and most radical since the origin of capitalism. It is accentuated by the Digital Revolution. We must not forget other "Revolutions" either: the Taylorization and Fordisme at the beginning of the $20^{\text {th }}$ century.

Boussard (2008) defines "managerial ideology" as based on thee main points: monitoring and controlling an organization (the main justification of management), aiming at enabling organizations to be effective and efficient and finally relying on a rational and methodical approach to problems. The three keywords of management are: control, performance and rationality (Boussard 2008, pp. 25-27).

The dislocation of companies corresponds to the development of outsourcing, contributing to control and evaluation of results (regarding the goals contracted). The evaluation (assessment) began in the Anglo-Saxon countries and in private companies. In France, it gradually extended to the Public Sector (traditionally important in France) with the NMP (New Public Management / Nouveau Management Public), which gradually developed in the 1980s, succeeding to the PPBS (Planning Programming Budgeting System) and in France RCB (Rationalization of Budget Choices). The main idea of the NMP is to transpose management methods of the private sector to the public sector in order to improve efficiency, relying on the "3 Es": Economy, Effectiveness and Efficiency. Since 1996 when the Social Budget of the Nation in France became higher than the State Budget, Parliament members voted for the annual LFSS (Law of Financing Social Security / Loi de Financement de la Sécurité Sociale). Later came the logic around goals or outcomes imposed by the LOLF (Organic Law of Public Finance / Loi Organique des Finances Publiques), which gradually after 2003 transformed all management processes in the Public Sector, including universities (dashboards, indicators) and the focus on PPP (Partenariats Public Privé).

As a result our society has progressively become a "society of mistrust", as trust is a main stake. Standards are said to help "build confidence in an era of suspicion." In this perspective, D'Almeida (2001) emphasized the role of brands, labels and trade marks of companies and their products. These "work as safeguards to promote the security and sustainability of the exchange, 
matching supply and demand in selective criteria clearly identified" (D'Almeida 2001, p. 242).

D'Almeida (with men like Boutinet, Gramaccia) show how the project process, which is seen as increasingly natural in companies (Boutinet 2001), leads to a focus on innovations and has almost become an affair of State. The project process is at the heart of the modernization of the State as viewed by Rocard's government in 1989. Developed in a competitive market space, the project has also been put at the service of improving the functioning of the State services, seeking to move the system from administration around procedures to administration with responsibility (D'Almeida 2006).

The project, as a network for innovation, has become a symbol of our post-industrial society. This system has been implemented with notions of performance and efficiency and in relation with quality approaches. This article aims to outline the role of Quality approaches. Born in Japan after 1945 , the notion of quality was developed in the industrial field in a process of continuous improvement (kaizen). This gradually became Total Quality Management (TQM), and expanded to the Western world in the 1980s. It then expanded to all sectors of organizations, whether private or public, and was backed by statements of procedures and certification corporations (ISO, AFNOR in France) and the development of references as standards of measure.

Thevenot (1997) points to the evolution towards a "government by the standards" linked to market development, including the construction of the European market in the context of globalization. The rise of normalization corresponds to the competition in the market and is thus an integrated part of capitalism. Thevenot (1997) outlines the extension of the standardization area from that of goods, products and services to that of people (standardization of skills). It's a process to standardize objects or acts in order to bring consistency to an efficient industrial operation (Taylorization). The challenge is to ensure new surrounding formal contractual relations between individual subjects, with the risk of information dominated by a uniform standard of cognition.

The evolution of the notion of standards has met two other major issues in the last sixty years: the development of the Welfare State and the development of services (tertiary sector) with the shift to the "taylorization of services". The Welfare State, often interventionist, particularly in France, has gradually evolved to become more of a guide, a motivator and an arbitrator. This in a context of limited resources, deep deficits and higher charges, has implied a tighter cooperation with the private sector. With a Social or Welfare Budget which amount is larger than that of the State's itself during the last twenty years, the State has been forced to delegate, develop partnerships with the private sector and learn to "manage risk", especially financially. At the same time, Western Societies have become Service Societies, since the service sector now counts for nearly 75 percent of the active working population, with a high proportion of "knowledge workers."

\subsection{Standards and Assessment for improving Quality}

According to AFNOR (French Standards Association or Association Française de Normalisation), the best way to introduce standards and norms is to recall the definitions of "standard" as proposed in ISO/CEI ${ }^{2}$. Standardization is an "activity of establishing, in front of real or potential problem, provisions for common and repeated use, aimed at obtaining the optimum degree of order in a given context." The document states that "this activity involves, in particular, the formulation, dissemination and implementation of standards." It says that standardization offers significant advantages, including better adaptation of products, processes and services for which they are assigned, for the prevention of trade barriers and facilitating technology cooperation. The same guide outlines that "the standards are based on the consolidated results of science, technology and experience and seek the optimum benefit of the community."

We shall retain the ideas of "common and repeated use for obtaining optimum degree of order in a given context and facilitate cooperation". All organizations, private companies or public sector agencies, have developed customer approaches based on standards and benchmarks to ensure the quality of the services offered. The change has largely concerned management devices which have proliferated in all organizations. Boussard (2006) conclude that "the management devices between organizational and professional standards" Systems of standardization (of quality, security) about integration of information (ERP: Enterprise Resource Planning) and assessment (of skills, of financial results), are imperative in the name of the ideal organization, which is rational and efficient because regulated and controlled. According to Boussard (2008), these management devices constitute the privileged support of the the "makers of performance". This article comes to a key point:

\footnotetext{
${ }^{2}$ Normalisation et activités connexes - Vocabulaire général (2004), European Standard reference EN 45020, in France NF EN 45020.using ISO definitions (International Standards Organization), Website :

http://www.bivi.metrologie.afnor.org/ofm/metrologie/i/i20/i-20-10/4 (visited on September 2010, $25^{\text {th }}$ ).
} 
the link between standards, productivity and the evaluation of the performance.

The development of a "government by the standards" and by the quantitative techniques of management is inseparable from evaluation. The use of increasingly important sub-contracting (outsourcing) or of a delegation and contracting approach can be defined as an objective or outcome approach and requires an assessment of the results obtained by the contracting party in comparison with the targets written in the original contract. States often try to master huge deficits, particularly in the Health sector in France.

Lievre invites J. Plante who defines "assessment as the formation of value judgment on action in the perspective of decision making." Plante continues: "the quality of an assessment lies in the degree of integration of the results produced in the representations to come of the sponsors" (Lievre 2002 , pp. 22-23). In the public sector or quasipublic social protection in France, these notions of standardization and evaluation correspond to the proliferation of different agencies. For example in the Healthcare sector, France developed ANDEM (National Agency for the Development of Evaluation in Medicine), established in 1990, then in 1997 it became ANAES (National Agency for Assessment and Accreditation in Health) and finally it became the High Authority for Health (HAS) in 2005. Then there is the AFSSAPS for sanitary security and health products. In the case of Healthcare Networks, devices of cooperation between public and private sectors wanting to articulate the activities of the hospital and primary care, it is outlined that: "The assessment of Healthcare Networks means to appreciate the achievement of qualitative and quantitative goals to measure their impact on the quality of care for patients, the quality of access to care, practices of Health professionals and on all the context of these Healthcare Networks." ${ }^{3}$ The risks of drifts from a "government by the standards" are important in this case. The pointillist application of guidebooks and procedures (to take documents literally) can override the main spirit, forgetting the importance of context, as the cult of quantitative approaches overriding more qualitative approaches.

Quality does not amount to the only application of standards. It constitutes above all a state of mind, a culture modulating behaviour, and a way of being and know how to face situations ${ }^{4}$.

\footnotetext{
${ }^{3}$ Circular CNAMTS (Health Insurance)/DHOS - Ministry of Health (March $2^{\text {th }}$, 2007) about orientations for evolution of Healthcare Networks in France, p. 2.

4 Ecole des Enseignants-Chercheurs en Qualité, CNQP (Comité National de la Qualité et de la Performance) Université de Technologie de Compiègne (UTC), Paris, Negocia, 27 janvier 2011.
}

Quality is not only standards; it is not only order or rule without meaning. It is rule and meaning. The problem is when we have rules without meaning or against meaning.

\subsection{The Cult of Standards or the Risk of Efficiency Obsession in a too exclusive quantitative approach}

Alémanno-Parrini and Le Moënne (2010) have outlined how the issue of evaluation of professional practices has become central in various sectors, including that of home services. Alémanno-Parrini and Moënne (2010) conclude that: "this concept is obviously ambivalent. Sometimes value judgment focused on practices, based on estimations of disparities with the specifications or expected results, in the case of projects (with extremely passionate reactions and mass movements of resistance). It can also be understood as a device for improvement or as an overall issue of resource management". This ambivalence is between the possibility of improvement and instrumental control.

The rise of "performance devices" refers to the "injunction to professionalism" that "most often come into collision with the ideas that the professionals themselves have about their activity" (Boussard, Demazière \& Milburn, 2010). In the Healthcare sector and especially in the hospital, Schweyer (2010) highlights the tension between costs (administrative and economic point of view about efficiency, corresponding to a will to control expenditure) and values (of the different professions). The central objective of cost containment in the Healthcare sector is also based on standards.

Mintzberg (2001) is particularly vehement in his denunciation of the drifts of a too exclusively quantitative approach, notably in "Note on an ugly word: efficiency." 5 For Mintzberg (2001) "management, as practiced now, may be causing the problem and do not propose the solution. It can work against our vital interests (...) a management obsessed with the idea of efficiency is a management obsessed with the idea of the quantifiable. The cult of efficiency became the cult of the quantifiable. And here lies the real problem (...) Because the economic benefits are more easily quantifiable than the social benefits, efficiency often leads the organization to adopt an economic ideology that can sometimes mean social immorality" (Mintzberg 2001, pp. 479-485). Critics of Mintzberg are met by De Gaulejac (2009) when

\footnotetext{
${ }^{5}$ MINTZBERG H (2001), « Remarque sur un bien vilain mot : "efficience"», in Le Management. Voyage au centre des organisations, Paris, Ed. d'Organisation, p. $479-485$.
} 
he denounces the "society sick of management". De Gaulejac (2009) concudes in his preface that "disease of management becomes an epidemic." He stresses the point that "management by project became the model of governance." "The performance is not measured by the quality of service delivered, but only in terms of cost and financial results." De Gaulejac (2009), who has been associated with the creation of the University of Management in Paris Dauphine, emphasizes that "our purpose is not to condemn management. Management is necessary to optimize the functioning of organizations and administrations. It is not bad in itself. It becomes bad when, with the pretext of reform or rationalization, tools are applied blindly, without concern for human consequences, organizational and social (...) When management is at the service of instrumental rationality, it loses its legitimacy" (De Gaulejac 2009, pp. $9-13$ ).

There are examples of drifts, in France, as in the case of companies like France Telecom (Orange), known for scandals of moral harassment or in the Pôle Emploi (French Organization for Unemployment). Scepticism has also be directed towards the gap between the display of "quality certification" in RATP (Underground company in Paris) and at SNCF (French Railways) stations. The reality perceived by the users is of a sharp deterioration of the service during the last years. This is also the case in call centers (symbols of the "Taylorization" of services), where quality guidelines emphasize the speed of response and limitation of waiting times, which is praiseworthy, but these guidelines rarely mention the quality and the added value of the information given to users. In order to stick to quality procedures, these users have become "customers", even in the Public Services. In parodying the title of the work of Ehrenberg (2000) on the "tiredness of being oneself" about an "individual uncertain, more and more exhausted by the "cult of performance". Jeannot (2010) speaks of the "tiredness of being a customer", also in the Public Sector. Jeannot (2010) stresses that these are not "users" who wish to become "customers". It is a "managerial standard", highly debatable, since the so-called customer has no real choice between different service providers. This "king customer" is more "confused", in "probation freedom" or suffering "pressures close to the forced sale" (Jeannot 2010, pp. 35-39).

The emphasis is strongly on information and communication, but Wolton (2009) among others, states that "to inform is not to communicate." That is the question of meaning, especially in the public sector where the notions of "public service" and "public interest" no longer seem to have the same significance.

\section{Methodology}

Our approach relies on a literature review and mainly on a qualitative method (with emphasis on qualitative and not just in the speeches of leaders and in the titles of laws, but in the reality of daily activity), nevertheless without neglecting the quantitative aspects. A first step is to measure the gap existing between the official speeches of the leaders and the daily reality lived by employees.

The question of meaning is critical, as in any approach linked with the "intelligence of complexity", by giving full value to autonomy and responsibility of "knowledge workers" (Dortier 2005). The question is also essential in the answers proposed both by Mintzberg and by De Gaulejac. They outline the imperative to "give meaning to action", changing the point of view from the "employee as a resource" to the valorization of the "individual subject" and so a "more human management of resources" (De Gaulejac 2009, pp. 302-310). With the equally critical issue of developing trust (Le Cardinal): in oneself, in others and in the future, in the people and in sociotechnical devices.

Beyond standards, it is necessary to bet on the intelligence of the relationship. Thus we meet both N. D'Almeida (2001), who insists on a "relationship economy" with all the importance of Networks and Zacklad (2009) with his "economies of conviviality" and his "semiotics of cooperative transactions".

\section{Standards and Competitive Intelligence not always an easy relationship}

These developments and shifts, which increase the gap between the noisy and incantatory speeches which are "customer focused" and the reality perceived by the so-called customer about the deterioration of delivered services, can contribute to the degradation of the image of companies. Thus, the excesses of a "government by the standards" and of performance only considered in quantitative terms ask the question about the difficult relationship between Standards and Competitive Intelligence.

According to Levet (2001), "Competitive Intelligence is the ability to understand our environment and to anticipate change (...) It is based on mastering information and on the production of new knowledge" (Levet 2001, VII). The Intelligence Economique Mémo, prepared by the French National Gendarmerie (2006) distinguishes three families of threats for a company: 1) the damage to image and reputation 2) exposure to economic and financial risks 3 ) risks of information and know-how. The document, Intelligence Economique Mémo, thus clearly 
distinguishes between human threats and technological threats.

For Le Bas and Picard (2003), if "information is at the heart of any Competitive Intelligence device (...) it is no longer considered as a scarce resource (...) But what became rare and may be considered as a source of competitive advantage for companies that control this resource, they are the skills needed to use, to interpret, or assimilate information" (Le Bas \& Picard 2003, p. 17). In an organization that turns into a "learning organization", workers become "knowledge workers" (Dortier, 2005). Moral harassment and lack of motivation among employees may constitute a major risk for the company, resulting in Risk Management at different levels, a major concern for the function of Competitive Intelligence.

Holmes (2002) refers to Bernstein, for whom, "the boundary between Modern Times and the Past is the mastery of risk" (Holmes 2002, p. 2). For Bernstein, "Risk Management is an active process" (Holmes 2002, p. 6) concerned with "the relationship between risk and change" (Holmes 2002 , p. 8). Introducing new management methods and methods for assessing performance, standards induce powerful changes in human relations and in the lives of individuals, and all of these consequences are normally not taken into account in CI analysis as analysts try to select the best scenarios.

For their part, Metayer and Hirsch (2007) insist on ethical risks and human needs in the company, referring to Maslow's pyramid: need for belonging and of self respect and need for achievement. In this article emphasis has been on risks that the standards applied rigidly, expressed as instrumentalization. The standards used properly can contribute to a positive image of the company by improving the quality perceived by customers. These standards can also improve cooperation between organizations, especially in the context of globalization. It is only in their drifts, also for the project (Boutinet) - standards and project often being associated - that they constitute a risk for companies.

\subsection{A different approach to Standards and Competitive Intelligence Relationship}

The author believe that another approach of the relationship between Standards, Assessment and Competitive Intelligence is possible, especially based on the concept of "reliance", important in the interdisciplinary of Information and Communication Sciences (ICS).

Bernard (2006) positions the Information and Communication Sciences at the articulation of four issues: relationship, meaning, knowledge and action. Ollivier (2000) points out three issues: meaning, power and identity. The question of meaning is essential. It is at the heart of the specificity of ICS, by providing the question of interactions with that of relationship (interactions or relationship) with knowledge and with action (issues of representations), and with the joint issues of Competitive Intelligence as an aid to decision making in a strategic perspective. The human dimension is essential. Wolton (2009) emphasizes that to "think communication is to think the lack of communication, he speaks of "incommunication". For Wolton "to communicate is less and less about how to transfer, rarely to share, but usually to negotiate and finally to cohabit" (Wolton 2009, p. 94).

This importance of meaning must be enhanced in relation to the notions of situation and contextualization as expressed by Mucchielli (2010) through his approach of "Situational Semiotic". Mucchielli proposes to analyze situations for an actor from different frameworks or contexts: through identification of actors, positioning of actors, space and temporal contexts, standards, values, quality of relationships. These should be applied to standards in companies, for goods or services, for a wider general use in society (social norms) but also as a method, as for technical requirements to supervise activities, standards established by ISO or French AFNOR. This is the subject of this communication. It is essential for "Situational Semiotic" to analyze the situation for any actor following these dimensions for reflection.

The ICS approach tries to answer the central question of the meaning of the activity, recognizing issues that are central in management for a more complex approach. Genelot (2001) stresses the importance of "making sense" and "build a culture", by "putting the human being at the heart of the company", "knowing how to recognize and articulate different logics to go back to the source of representations" (Genelot 2001, pp. 336 - 340).

\subsection{Standards: an example of the Globalization only for the benefit of its dominant countries and companies?}

Besides their weight of standards on the evolution of organizations, including those imposed through socio-technical devices such as information systems or management, standards are also a strategic issue for Economic Globalization.

The competition between companies and countries is now global, both in the field of industrial products (cars, computers, machine tools and so on) but also in services (energy, insurance, banking, retail, transport, telecommunications and so on). Producers seek to generate margins in one battle at a time, all centered around cost, sales, and 
the setting of prices as essential in the context of fierce competition. For their part, buyers and regulators seek qualitative benchmarks, for selecting the most competitive, rather than the less expensive suppliers or contractors. In this perspective, as already stressed by D'Almeida, the company's image and its reputation (around the concept of brand) can be valuable with all the challenges of e-reputation or reputation by examining information from Internet. Standards and certifications (as recognized signs of quality) may also help to develop the confidence of buyers and consumers and, therefore, constitute a strategic issue for companies, as part of a Competitive Intelligence analysis.

The definition of standards is presented in basic documents published by the Standards' Organizations as the result of a consensus. In this article the author questions the weight of the AngloSaxon countries and companies, especially United States of America, particularly in the ISO (International Organization for Standards) which, by progressive or more coercive methods, contribute to impose standards on the rest of the world. These standards correspond to their particular approach and interests, helping to create a competitive advantage for their own businesses. Other standard organizations such as AFNOR in France, integrate and use the standards proposed by ISO, more or less willingly. As for patents and industrial property, the standards battle is a major issue for the credibility of the European Union and the economic weight of the countries of the Old Continent in the global marketplace.

After the quasi abandonment of the national policy of Scientific and Technical Information in France in the 90's, hope was placed on the European level. Worries have been expressed about the recent draft agreement (in December, 2010) between the European Patent Organization (EPO) and Google for the translation of the European patents ${ }^{6}$.

The stakes are particularly high in the field of standards, concerning the production of industrial goods or services, but there is also a key issue around accounting standards, as demonstrated by Capron (2007). Capron (2007) has stressed that in France, accounting is often perceived as a neutral technique (also often perceived as esoteric) that may be required objectively. Furthermore, Capron (2007) states that it is above all a social convention, historically dated, evolutionary, developed according to the big economic movements, more or less buffeted by conflicting pressures and intended to produce economic and social effects, the most important thing is bringing confidence in trading.

\footnotetext{
${ }^{6}$ La Dépêche du GFII (Groupement Français des Industries de l'Information) 2010, December $1^{\text {st }}$.
}

By focusing only on learning the ways of recording and bookkeeping system, France is in a vulnerable position, not reconsidering the foundations of the accounting systems. This includes the principles that guide accounting choices: any accounting system is a choice of representation of the economic and financial reality among many other possibilities. This instrumental and technical approach impedes being aware of the diversity of accounting systems in the world and across time, and more importantly, to underestimate the importance of valuation methods and valuation of companies. These are crucial to define the value of companies in case of purchase and also for taxation. Taxation is dependent on the criteria for evaluating benefits and benefits in term depend on provisions and depreciations. For example AngloSaxon accounting systems grant more freedom to the accounting players as shown in the case of Enron (2001). As seen afterwards, this perspective of the accounting system must be questioned. It is for the Competitive Intelligence function to detect its weaknesses in advance. Thus questioning the whole system becomes its domain.

\section{Conclusion and future research}

Standards, Certification and Evaluation are key areas which influence the future of our world. The field of CI must be aware of the stakes. In this article the author has showed the risk of our existing standards in the form of certification and evaluation, which may lead to an obsession with instrumental and quantitative techniques. Examples of this is stressed by Mintzberg (2001) and De Gaulejac (2009), where the subtitle of the book is "managerial ideology, managerial power and social harassment." We must not deny the interest of management or the standards for the development of confidence, both for consumers and policy makers, to ensure the quality of goods and services, but must also foster comparisons.

It is necessary to assess all the issues (not always seen) in the field of standards, both in the overall context of the globalization of trade and markets, but also the risks of abuses in daily activities in enterprises and organizations. The technique or even the idea of progress itself, standards, certification and evaluation, and more widely Quality approaches, are at the end ambivalent. They must be seen as tools and not as an end in themselves.

In this perspective, the problems of the relationship, meaning, knowledge and action, as presented in an ICS (Information and Communication Sciences) approach are essential. This approach values the importance of the investment in the field of standards, certification and assessment by Competitive Intelligence actors, 
to restore its relational and human dimensions (not leaving it only to engineers and technicians) both at the strategic, the policy (macro), and day-to-day working (micro) levels. The challenge is to create relationship and meaning to have better choices. In this spirit the author has also wanted to offer some areas for future research linked with challenges in the development of trust, meaning and cooperation in a new qualitative approach around "Quality 2.0" or "Sustainable Quality".

In what can be called the stereotypical speeches of main world organizations (such as WTO: World Trade Organization), some States and large companies insist on the benefits of free global competition for consumers. Many are questioning whether or not these are smokescreens, trying to hide a manipulation. Strategic issues such as standards, are they not often ultimately a tool for domination of a few countries and for big multinational companies?

More broadly, does not the unbridled pursuit of profit through the obsession of performance and efficiency (Stiglitz speaks about "cupidity") risk to forget the quality, in the best sense of the word, sacrificing for example the healthcare and the environment because it is not profitable? The relationship between standards and the study of Competitive Intelligence here meets the challenges of sustainable development, outlining the limits of the current globalization process.

\section{References}

ALÉMANNO-PARRINI, S., LE MOËNNE, C. 2010. Appel à contributions pour le $\mathrm{n}^{\circ} 38$ : «Evaluation, communication?», Revue Communication \& Organisation: http://www.fabula.org/actualites/communication -et-organisation-n38-evaluation-

communication_39084.php (visited on December $20113^{\text {rd }}$ ).

AVENIER, MJ. 1997. Le Management stratégique dans la complexité: un cadre de réflexion, consultable sur http://www.strategieaims.com/montreal/avenier.pdf

BERNARD, F. 2006. «Les SIC une discipline de l'ouverture et du décloisonnement», in BOUZON (Arlette) sous la dir. de, $L a$ communication organisationnelle en débat. Champs, concepts, perspectives, Paris, L'Harmattan, pp. $33-46$.

BOUSSARD, V., DEMAZIERE, D., MILBURN, P. 2010. L'injonction au professionnalisme. Analyses d'une dynamique plurielle, Presses Universitaires de Rennes, $176 \mathrm{p}$.

BOUSSARD, V. 2008. Sociologie de la gestion. Les faiseurs de performance, Paris, Belin, 263 p.
BOUSSARD, V. (Red.) 2005. Au nom de la norme: Les dispositifs de gestion entre normes organisationnelles et normes professionnelles, Paris, L'Harmattan, $224 \mathrm{p}$.

BOUTINET, JP. 2001. Anthropologie du projet, Paris, PUF, $6^{\mathrm{e}}$ éd., $350 \mathrm{p}$.

CACALY, S., LE COADIC, YF., POMART, PD. and SUTTER, E. 2008. Dictionnaire de l'information, Armand Colin, $3^{\mathrm{e}}$ éd., 294 p.

CAPRON, M. 2007. «Les enjeux de la mondialisation des normes comptables », L'Economie politique, 2007 / 4, $\mathrm{n}^{\circ} 36$.

CARAYOL, V. 2004. Communication organisationnelle. Une perspective allagmatique, Paris, L'Harmattan, 235 p.

D’ALMEIDA, N. 2006. «Les organisations entre projets et récits », in BOUZON (Arlette) dir., La communication organisationnelle en débats. Champs, concepts et perspectives, Paris, L'Harmattan, p. 145 - 158.

D'ALMEIDA, N. 2007. Les promesses de la communication, Paris, PUF, 2001, rééd., 2007, $264 \mathrm{p}$.

DAVID, A. (red.) 2010. Intelligence Economique et problèmes décisionnels, Paris, Ed. Hermes Lavoisier.

DIAZ-BONE, R., THÉVENOT, L. 2010. «La sociologie des conventions. La théorie des conventions, élément central des nouvelles sciences sociales françaises », Trivium, 52010 : http://trivium.revues.org/index3626.html. (visited on June $201027^{\text {th }}$ ).

DORTIER, JF. 2005. «Les professionnels de l'intelligence : portrait de groupe », Les travailleurs du savoir, Sciences Humaines, $\mathrm{n}^{\circ}$ 157 , pp. 28 - 33.

EHRENBERG, A. 1991. Le culte de la performance, Paris, Calmann-Lévy.

ELLUL, J. 2001. La technique ou l'enjeu du siècle, Paris, Economica, 1990, rééd. 2001, 423 p.

GAULEJAC, V. 2009. La société malade de la gestion. Idéologie gestionnaire, pouvoir managérial et harcèlement social, Paris, 2005, nouvelle éd., Points-Seuil, 353 p.

Gendarmerie Nationale (2006) Mémo Intelligence Economique, 55 p.

GENELOT, D. 2001. Manager dans la complexité, Paris, INSEP Consulting, $357 \mathrm{p}$.

GUILHON, B., LEVET, JL. (reds.) 2003. De l'Intelligence Economique à l'Economie de la Connaissance, Paris, Economica, 199 p.

HOLMES, A. 2002. Risk Management, Oxford, Capstone Publishing, $122 \mathrm{p}$.

JEANNOT, G. 2010. «La fatigue d'être client », Informations sociales, Les services publics face à leurs usagers, $n^{\circ} 158$, pp. $34-41$.

LEBAS, C., PICARD, F. 2003. «Intelligence économique, analyse stratégique évolutionniste et compétences de l'organisation », in 
GUILHON, B., LEVET, JL. (reds.) De l'Intelligence Economique à l'Economie de la Connaissance, Paris, Economica, pp. 15 - 31.

LE MOËNNE, C. 2004. « La communication organisationnelle à l'heure de la dislocation spatio-temporelle des entreprises. La mutation des formes organisationnelles », Sciences de la Société, in CHESSEL, M.-E., COCHOY, F. dir., Marché et politique. Autour de la consommation engagée, Toulouse, LERASS, Presses Universitaires du Mirail, ${ }^{\circ}$ 62, 2004, pp. $209-224$.

LEVET, JL. 2001. L'Intelligence Economique. Mode de pensée, mode d'action, Paris, Economica, $154 \mathrm{p}$.

LIEVRE, P. 2002, Evaluer une action sociale, Rennes, Ed. ENSP, 115 p.

MAYÈRE, A. 1990. Pour une économie de l'information, Paris, Editions du CNRS.

MÉTAYER, Y., HIRSCH, L. 2007. Premiers pas dans le management des risques, Paris, Afnor, 2007, $135 \mathrm{p}$.

MIÈGE, B. 2004. L'information-communication objet de connaissance, De Boeck, Bruxelles, $248 \mathrm{p}$.

MINTZBERG, H. 2002. "Nous vivons dans le culte du management», entretien, in Les organisations. Etat des savoirs, CABIN (Philippe) coord. par, Editions Sciences Humaines, Auxerre, pp. 91 - 97.

MINTZBERG, H. 2001. Le Management. Voyage au centre des organisations, Paris, Ed. d'Organisation, $570 \mathrm{p}$.

MORIN, E., LE MOIGNE, JL. 2003. L'intelligence de la complexité, Paris, L'Harmattan, $332 \mathrm{p}$.

MUCCHIELLI, A. 2010. Communication \& Influence. Approche situationnelle, Editions Ovadia, Nice - Genève - Paris - Bruxelles Montréal, $124 \mathrm{p}$.

MUCCHIELLI, A. 2001. Les sciences de l'information et de la communication, Hachette Supérieur, $3^{\mathrm{e}}$ éd., $158 \mathrm{p}$.

OLLIVIER, B. 2000. Observer la communication. Naissance d'une interdiscipline, CNRS Editions, Paris, $184 \mathrm{p}$.

PLANTE, J. 1991. Principes d'une évaluation socialement utile. Leçons d'une expérience québécoise », in Outils, pratiques, institutions pour évaluer les politiques publiques, Paris, La Documentation française.

SCHWEYER, FX. 2010. «Hôpital, une tension entre coûts et valeurs", in HALPERN (Catherine) coord. par, La Santé. Un enjeu de société, Auxerre, Ed. Sciences Humaines, pp. $278-287$.

THÉVENOT, L. 1997. «Un gouvernement par les normes. Pratiques et politiques des formats d'information », in CONEIN, B., THEVENOT,
L. dir., Cognition et information en société, Paris, Editions de l'EHESS, pp. 205 - 242.

WOLTON, D. 2009. Informer n'est pas communiquer, Paris, CNRS Editions, $147 \mathrm{p}$.

ZACKLAD, M. 2009. «Les économies de la convivialité dans les sociétés de l'information et des services », Leçon inaugurale, Paris, CNAM, 17 juin 2009.

\section{Web sites accessed}

AFNOR (Association Française de Normalisation) : www.afnor.org

Association pour la Pensée Complexe. Programme européen «Modélisation de la CompleXité »: http://mcxapc.org

ISO (International Standards Organisation): www.iso.org 